\title{
Spatial and Temporal Variation of Urban Air Quality: A GIS Approach
}

\author{
Subrata Chattopadhyay ${ }^{1}$, Srimanta Gupta ${ }^{1}$, Raj Narayan Saha ${ }^{2}$ \\ ${ }^{1}$ Department of Environmental Science, The University of Burdwan, Burdwan, India; ${ }^{2}$ Department of Chemistry, National Institute \\ of Technology, Durgapur, India. \\ Email: srimantagupta@yahoo.co.in
}

Received May $19^{\text {th }}, 2010$; revised June $5^{\text {th }}, 2010$; accepted June $19^{\text {th }}, 2010$.

\begin{abstract}
This study investigated the seasonal variation of ambient air quality status of Burdwan town using GIS approach. Concentration of $\mathrm{SO}_{2}$ (sulphur dioxide), $\mathrm{NO}_{2}$ (nitrogen dioxide) and RSPM (respiratory suspended particulate matter) were measured once a week for 24 hour in both premonsoon and postmonsoon season. The seasonal average concentration of the RSPM, $\mathrm{SO}_{2}$ and $\mathrm{NO}_{2}$ in premonsoon season was observed to be $188.56 \pm 88.63,5.12 \pm 6.27$ and $92.51 \pm 64.78$ $\mu \mathrm{g} / \mathrm{m}^{3}$ respectively whereas in postmonsoon it was $53.03 \pm 38.27,8.51 \pm 7.11$ and $162.85 \pm 184.80 \mu \mathrm{g} / \mathrm{m}^{3}$ respectively. Statistical analysis showed the significant monsoonal effect on mean difference of RSPM, SO $\mathrm{S}_{2}$ and $\mathrm{NO}_{2}$ concentration. Postmonsoon concentration of ambient $\mathrm{SO}_{2}$ and $\mathrm{NO}_{2}$ were observed to be higher than premonsoon, suggesting longer residence times of these pollutants in the atmosphere due to stagnant conditions and low mixing height. Spatial distribution of pollutants throughout the town in both the season was represented by digital elevation model (DEM). On the basis of Air Quality Index (AQI) a GIS based air pollution surface models were generated in both the seasons by means of Inverse Distance Interpolation (IDINT) technique. From the output surface model it was found that in comparison to premonsoon there was a significant increase of clean and fairly clean area and decrease of moderately polluted area of the town during postmonsoon.
\end{abstract}

Keywords: Ambient Air Quality, Seasonal Variation, Air Quality Index (AQI), Geographic Information System (GIS)

\section{Introduction}

Throughout the world, air pollution is a matter of concern at all levels. The worldwide epidemiological study on the effect of air pollution had revealed that gaseous pollutants and particulate matter had enough potential to cause severe health effect like respiratory, cardiovascular diseases and cardio pulmonary mortality $[1,2]$. Being a serious matter of concern now-a-day, a systematic monitoring programme all over the world especially in urban cities are urgently needed as the level of air pollution is increasing rapidly in many areas of mega cities of the developing world [3]. It was found that the modernization and industrialization of developing countries had led to the increase use of fossil fuels and their derivatives. As such, developing countries were confronted with the great challenge of controlling the atmospheric pollution especially in the rapidly growing mega cities. Concern about air pollution in urban regions is receiving increasing importance world-wide, especially pollution by gase- ous and particulate trace metals [4-7]. The urban centers might be viewed as dense sources of enormous anthropogenic emissions of pollutants, which could alter the atmospheric composition, chemistry and life cycles in its down wind regimes, extending over several hundred kilometers [8]. It had been found that world motor vehicle population growth had reached 700 million in the year 2000 [9]. Petrol and diesels engines of motor vehicles were found to emit a wide variety pollutants, principally, oxide of nitrogen (NOx) which had an increasing impact on urban air quality [10]. Various monitoring programme had already been done in developing countries like Bangladesh and Pakistan [11,12].

In India, air pollution had also become a topic of intense debate at all levels mainly because of the enhanced anthropogenic activities [13]. Today India is one of the first ten industrial countries of the world [14]. Urban air pollution in India had increased rapidly with the population growth, numbers of motor vehicles, use of fuels with poor environmental performance, badly mentioned tran- 
sportation systems, poor land use pattern, and above all, ineffective environmental regulations [8,9]. Among the worst air city the name of the capital of India is enlisted followed by Beijing, China, Xian, Kathmandu, Dhaka in Asia. So far various research work had been done on spatial and temporal variation of urban air pollution in various cities of India like Kolkata, Delhi, Lucknow, Haryana, Chennai, Mumbai, Dhanbad-Jharia and on RaniganjAsansol [8,13,15-20].

GIS is used as a platform for spatio-temporal analysis or for building relationships between the GIS database and stand-alone modeling tools. Air data are generally very complex to model due to the underlying correlation among several pollutants. The significant differences among the results obtained from the techniques, indicated that proper air quality management requires sensitive air quality evaluation [21]. Various research work had also been done on the GIS aspect of spatio-temporal analysis of urban air quality [22-25].

Burdwan being a city of West Bengal state in eastern India and headquarters of Burdwan district now a day draws attention with respect to ambient air quality status. Not only being a busy town (populated by $2,85,871$ people as per 2001 census) but also being nearest to Durgapur, this place was given importance keeping in mind that Durgapur is the $7^{\text {th }}$ polluted city in India and air pollutants had the capacity to travel a long distance. Apart from several residential projects a major public private project "the largest heath city of Asia" was also proposed here. Medical report (Table 1), collected from the Govt. Hospital of this town, reflected that health problem due to air pollution is increasing day by day. So far no systematic air quality-monitoring programme with GIS approach was reported from this town. Hence the quality of ambient air deserved a systematic as well as scientific investigations so that proper strategies could be taken to mitigate in case of any pollution was found. The objective of this study was to evaluate the premonsoon and postmonsoon distribution of selected gaseous pollutants i.e. sulphur dioxide $\left(\mathrm{SO}_{2}\right)$, nitrogen dioxide $\left(\mathrm{NO}_{2}\right)$ and respiratory suspended particulate matter (RSPM) and its interaction with meteorological parameters. This study also performed to develop a GIS based air pollution surface model on the basis of air quality index (AQI) by using continuous surface generation technique.

\section{Methodology}

\subsection{Study Area}

Burdwan town is located at $23.25^{\circ} \mathrm{N}$ latitude and $87.85^{\circ}$ E longitude. It has an average elevation of 40 meters (131 feet). The city is situated a little less than $100 \mathrm{~km}$ northwest of Kolkata on the Grand Trunk Road (NH-2) and
Table 1. Medical record (2008) of respiratory disease in Burdwan municipality.

\begin{tabular}{cccc}
\hline Sl. No & Month & Case & Death \\
\hline 1. & January & 17 & 03 \\
2. & February & 12 & 01 \\
3. & March & 34 & 00 \\
4. & April & 09 & 01 \\
5. & May & 22 & 00 \\
6. & June & 19 & 05 \\
7. & July & 18 & 01 \\
8. & August & 04 & 01 \\
9. & September & 09 & 00 \\
10. & October & 16 & 01 \\
11. & November & 39 & 03 \\
12. & December & 30 & 00 \\
\hline
\end{tabular}

*Data Obtained from Medical Record Department Burdwan Medical College \& Hospital Burdwan, West Bengal.

eastern railway (Figure 1). It is a city with an increasing number people opting for better residential spaces and higher living standards. The number of registered motor vehicle in the town (according to 2007 statistics) was 3, 97,5509. On basis of land use/land cover classification map (Figure 2) the respective locations of sampling encompassing sensitive, residential and industrial areas were selected. Altogether 25 locations encompassing all the three areas were selected randomly for air quality monitoring (Figure 2). Details of the sampling locations are represented in Table 2. Mainly the schools, colleges, university and children parks are enlisted as sensitive zones whereas the places beside road and others residential areas are considered as residential zones and others as per Central Pollution Control Board (CPCB). The place where the industries (mainly rice mills in the study area) are aggregated is considered here as industrial zone.

\subsection{Sampling (6:00 A.M. to 6:00 A.M.) and Analysis of Gaseous Pollutants and Particulate Matter}

In both the seasons the sampling was done for twentyfour (24) hours at each site. The seasonal classification was followed as per specification laid by Indian meteorological department [26]. March, April and May months were considered as premonsoon season and June, July, August, and September were considered as postmonsoon season. Air quality parameter such as repairable suspended 


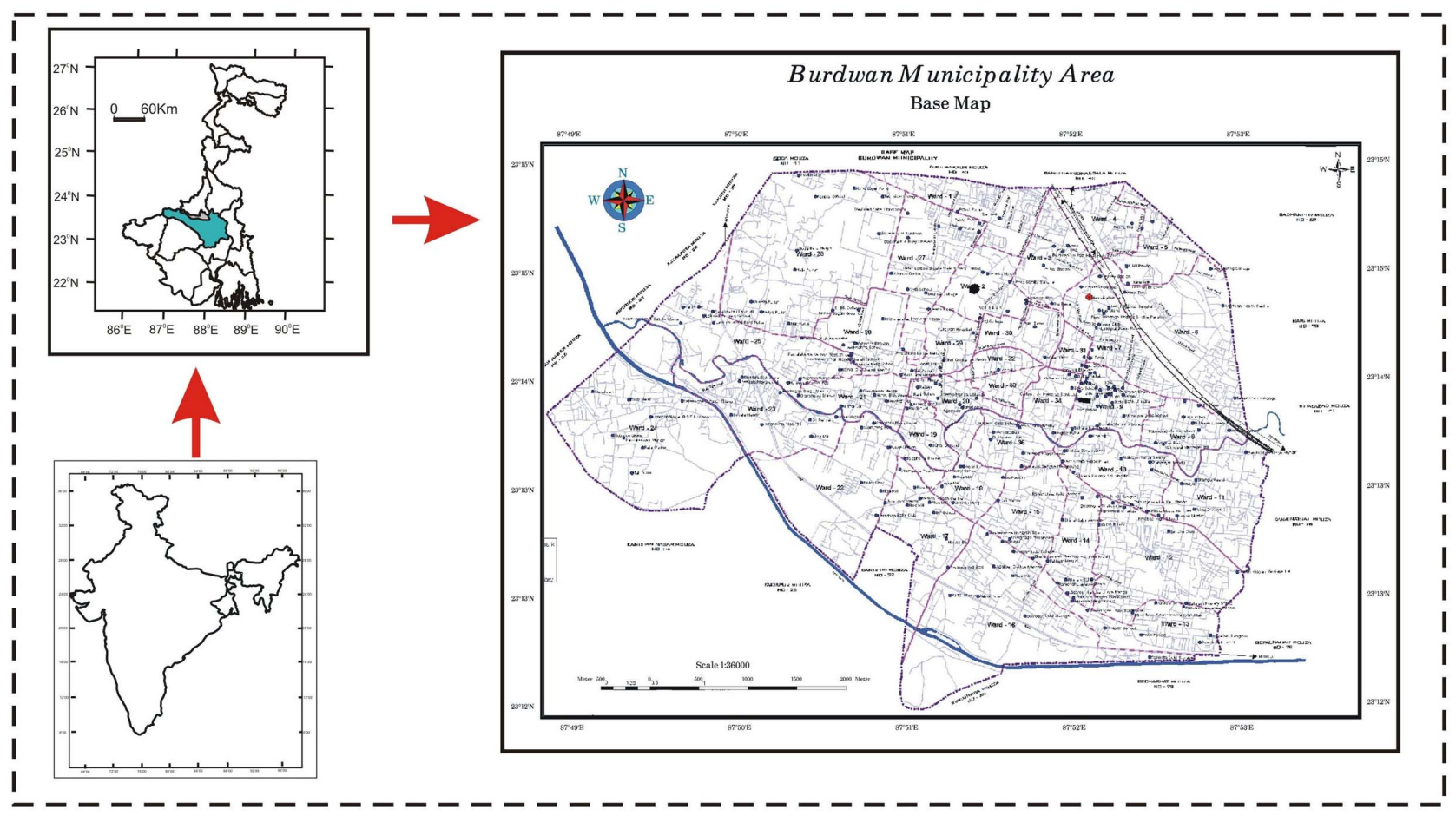

Figure 1. Study area location.
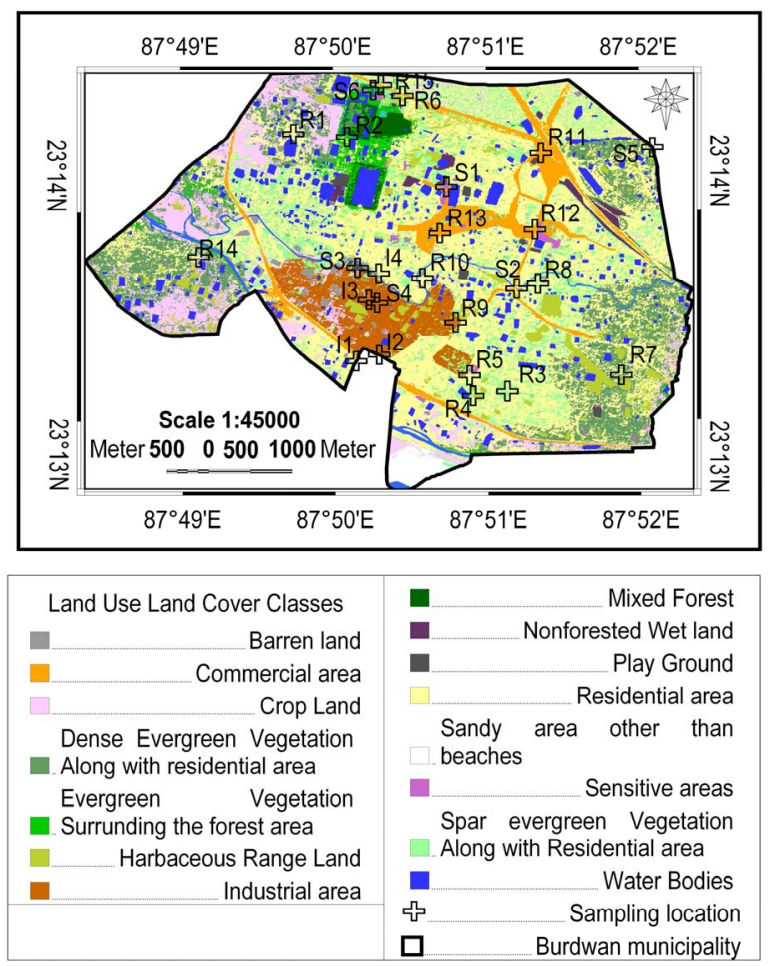

Figure 2. Land use/land cover map showing various sampling locations.

particulate matter (RSPM) which was also known as $\mathrm{PM}_{10}$
Table 2. Details of sampling sites.

\begin{tabular}{|c|c|}
\hline Sampling Sites & Description \\
\hline $\begin{array}{l}\text { R11, R12, R13, } \\
\text { R15, R6, R7 }\end{array}$ & Residential area with high traffic density \\
\hline $\begin{array}{l}\text { R3, R4, R5, R8, } \\
\text { R14 }\end{array}$ & Residential area with moderate traffic density \\
\hline $\mathrm{R} 1, \mathrm{R} 2, \mathrm{R} 10$ & Residential area with low traffic density \\
\hline R9 & $\begin{array}{c}\text { Residential area influenced by industrial } \\
\text { emission }\end{array}$ \\
\hline I1 and I2 & Industrial area with high traffic density \\
\hline I4 & Industrial area with moderate traffic density \\
\hline $\mathrm{I} 3$ & Industrial area with low traffic density \\
\hline S2, S5, S6 & Sensitive area with high traffic density \\
\hline S1 & Sensitive area with moderate traffic density \\
\hline S3 & $\begin{array}{l}\text { Sensitive area with moderate traffic density } \\
\text { and highly influenced by industrial emission }\end{array}$ \\
\hline S4 & $\begin{array}{l}\text { Sensitive area with high traffic and highly } \\
\text { influenced by industrial emission }\end{array}$ \\
\hline
\end{tabular}

was monitored by using High Volume Sampler (MODEL NPM HVS) following standard procedure by IS: 5182 (Part iv). Glass fiber filter paper, popularly known as GF/A filter paper was used and the flow rate was kept at $1-1.5 \mathrm{~m}^{3} / \mathrm{min}$. The model NPM HVS had a cyclone separator, which separated the coarser particulate matter larger than $10 \mu \mathrm{m}$ from air stream (drawn into the HVS) 
before filtering on GF/A filter paper. Air was also allowed to pass through two impingers having specific absorbing reagent for $\mathrm{SO}_{2}$ and $\mathrm{NO}_{2} . \mathrm{SO}_{2}$ and $\mathrm{NO}_{2}$ were collected by bubbling the sample in specific absorbing reagents of $25 \mathrm{ml}$ put in two impingers. The average flow rate through the impingers was $0.5 \mathrm{l} / \mathrm{min}$. After the sampling the impinger samples were kept in iceboxes and transferred to a freeze until the analysis was done. Sodium tetrachloromercurate and Sodium hydroxide were used as absorbing reagents for $\mathrm{SO}_{2}$ and $\mathrm{NO}_{2}$ respectively to arrest $\mathrm{SO}_{2}$ in the form of dichlorosulfitomercurate complex measured spectrophotometrically at $560 \mathrm{~nm}$ and $\mathrm{NO}_{2}$ as sodium nitrite measured at $540 \mathrm{~nm}$. For analysis of $\mathrm{SO}_{2}$ and $\mathrm{NO}_{2}$ by spectrophotometeric method, described in IS: 5182 (Part ii) and IS: 5182 (Part vi) were followed [27,28]. National ambient air quality standard (NAAQS) is represented in Table 3.

\subsection{Meteorology}

In each sampling location meteorological parameters such as humidity, temperature, wind speed, wind direction and rainfall were recorded both in premonsoon and postmonsoon seasons. Humidity and temperature were measured by a portable hygrometer (Model-HTC-1), rainfall is measured by a digital rain gauge (Model-RGR 126; Make-Oregon) meter whereas wind speed and direction is measured by a digital anemometer along with wind vane (Model-Lutron-AM-4201). For both the seasons two windrose diagrams (Figures 3(a) and (b)) were prepared by using windrose pro software. Apart from wind velocity and direction other meteorological data of the study area during monitoring period is represented in Table 4.

\subsection{Air Quality Index (AQI)}

An AQI could be defined as a scheme that transforms the (weighted) values of individual air pollution related parameters into single number. Air quality index [29] was also measured here for each place in each zone. At first air quality rating of each parameter used for monitoring is calculated in each zone by the formula as;

1) $\mathrm{q}=100 \mathrm{xV} / \mathrm{Vs}$; where $\mathrm{q}=$ quality rating; $\mathrm{V}=\mathrm{ob}-$ served value of parameter; $\mathrm{Vs}=$ value recommended for that parameter.

If total ' $n$ ' no of parameters were considered for air monitoring, then geometric mean of these ' $n$ ' number of quality ratings was calculated in the following way:

2) $g=$ anti $\log \{(\log a+\log b+\ldots \ldots \ldots \ldots \ldots \log x) / n\}$; where $\mathrm{g}=$ geometric mean; $\mathrm{a}, \mathrm{b}, \mathrm{c}, \mathrm{d}, \mathrm{x}=$ different values of air quality rating; and $n=$ number of values of air quality rating, $\log =\operatorname{logarithm}$.

Air quality status [30] on the basis of AQI is represented in Table 5.

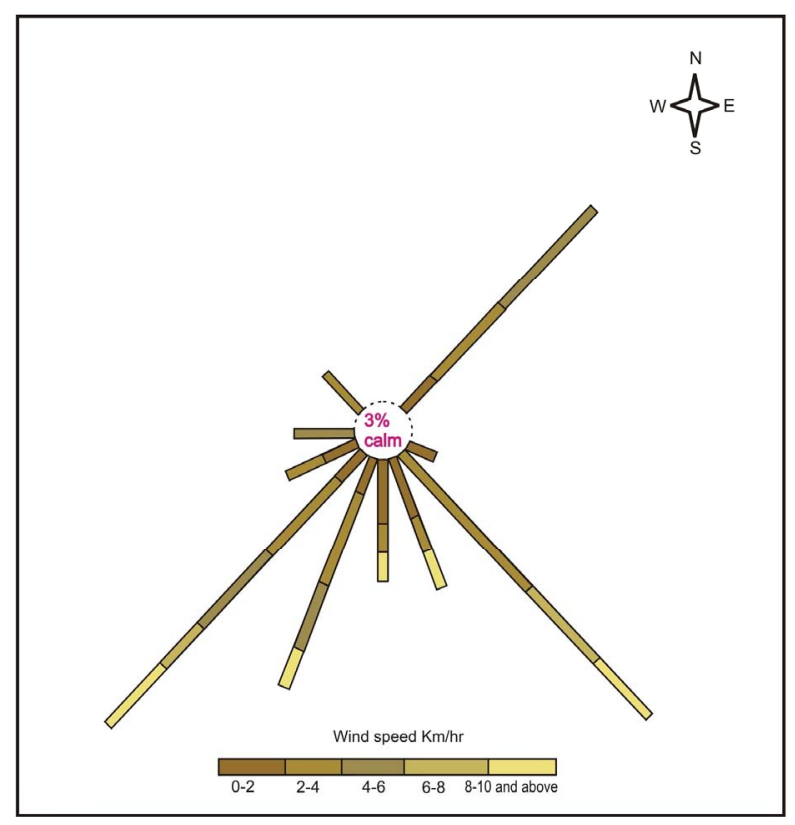

(a)

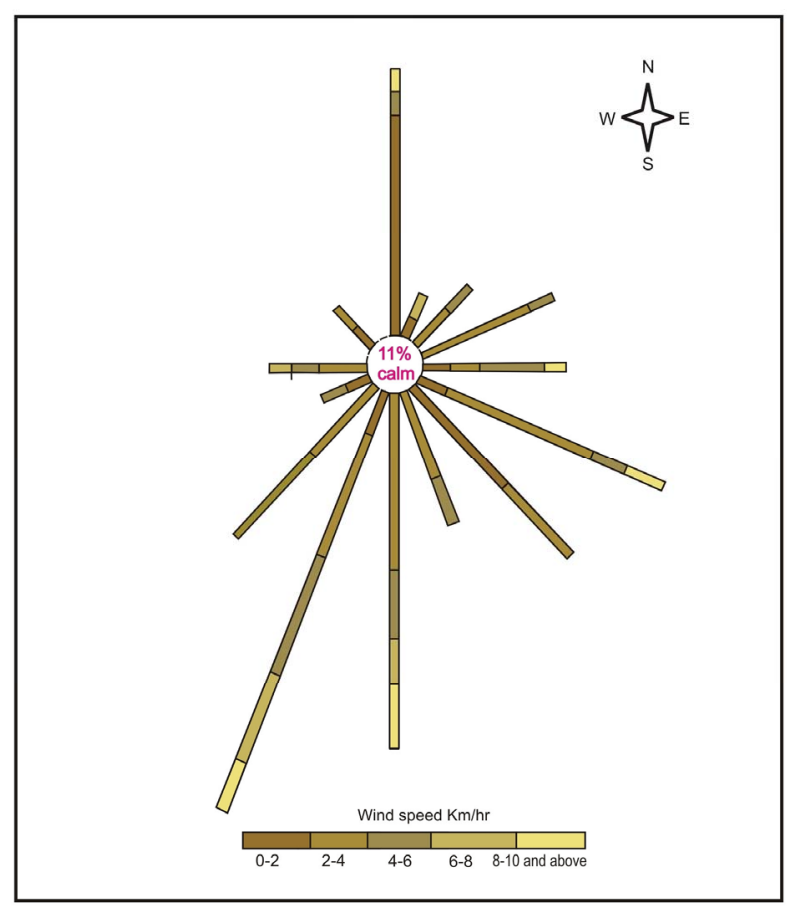

(b)

Figure 3. Windrose diagram. (a) Premonsoon; (b) Postmonsoon.

\subsection{Statistical Analysis}

\subsubsection{Pearson Correlation Coefficient}

The Pearson correlation among $\mathrm{SO}_{2}, \mathrm{NO}_{2}$ and RSPM was calculated by using the following formula 
Table 3. National ambient air quality standards.

\begin{tabular}{ccccc}
\hline Pollutants $\left(\mu \mathbf{g} / \mathbf{m}^{3}\right)$ & Time weighted & \multicolumn{2}{c}{ Concentration in ambient air in average } \\
\cline { 3 - 5 } & & Sensitive & Industrial & $\begin{array}{c}\text { Residential and } \\
\text { others }\end{array}$ \\
\hline $\begin{array}{c}\text { Respirable Suspended Particulate Matter } \\
(\mathrm{RSPM})\end{array}$ & $24 \mathrm{~h}$ & 75 & 150 & 100 \\
Sulphur dioxide $\left(\mathrm{SO}_{2}\right)$ & $24 \mathrm{~h}$ & 30 & 120 & 80 \\
Oxides of nitrogen $\left(\mathrm{NO}_{2}\right)$ & $24 \mathrm{~h}$ & 30 & 120 & 80 \\
\hline
\end{tabular}

Source: Central pollution control board, Delhi, 1994

Table 4. Meteorological condition during premonsoon and postmonsoon season.

\begin{tabular}{cccccc}
\hline $\begin{array}{c}\text { Meteorological } \\
\text { parameters }\end{array}$ & Maximum & Minimum & Average & Maximum & \multicolumn{2}{c}{ Postmonsoon } \\
\cline { 2 - 6 } & 118.7 & 42.7 & 78.8 & 433.6 & 228.2 \\
Rainfall $(\mathrm{mm})$ & 75 & 42.5 & 58.22 & 85 & 53 \\
Humidity $(\%)$ & 35.5 & 16.43 & 24.54 & 33.5 & 16.2 \\
Temperature $\left({ }^{\circ} \mathrm{C}\right)$ & & & 23.81 \\
\hline
\end{tabular}

Table 5. Air quality index table (Mudri, 1999).

\begin{tabular}{ccc}
\hline Category & $\begin{array}{c}\text { AQI of } \\
\text { ambient air }\end{array}$ & $\begin{array}{c}\text { Description of ambient air } \\
\text { quality }\end{array}$ \\
\hline I & Below 10 & Very clean \\
II & Between 10-25 & Clean \\
III & Between 25-50 & Fairly clean \\
IV & Between 50-75 & Moderately Polluted \\
V & Between 75-100 & Polluted \\
VI & Between 100-125 & Heavily polluted \\
VII & Above 125 & Severely polluted \\
\hline
\end{tabular}

$$
r=\frac{\sum_{i-1}^{x}\left(X_{i}-\bar{X}\right)\left(Y_{i}-\bar{Y}\right)}{(n-1) S_{x} S_{y}}
$$

where $X$ and $Y$ are two variables, with means $\bar{X}$ and $\bar{Y}$ respectively with standard deviations $S_{X}$ and $S_{Y}$. Statistical significance of $r$ value is calculated by $t$-test.

\subsubsection{Student's t-Test for Difference of Means}

A student's (t) test [31] was carried out for testing significant difference between means of factors for pre- and postmonsoon periods against left sided alternative hypothesis, i.e., the mean of premonsoon is less than that of the other. The test statistic, which follows t-distribution with $\left(n_{1}+n_{2}-2\right)$ degrees of freedom, is given by $t=\left(X_{1}\right.$ $\left.-\mathrm{X}_{2}\right) / \sqrt{\left(\mathrm{S}_{\mathrm{P}}{ }^{2} / \mathrm{n}_{1}-1\right)+\left(\mathrm{S}_{\mathrm{P}}{ }^{2} / \mathrm{n}_{2}-1\right)}$; where $\mathrm{S}_{\mathrm{P}}{ }^{2}=\left(\mathrm{n}_{1} \mathrm{~S}_{1}{ }^{2}+\right.$ $\left.\mathrm{n}_{2} \mathrm{~S}_{2}{ }^{2}\right) /\left(\mathrm{n}_{1}+\mathrm{n}_{2}\right)$.

$\mathrm{X}_{1}$ is the mean variable of premonsoon, $\mathrm{X}_{2}$ is the mean variable of post-monsoon, $\mathrm{S}_{\mathrm{P}}{ }^{2}$ is the variance of combined sample (Standard Error of difference between means of pre- and postmonsoon parameters), $\mathrm{n}_{1}$ is the number of observations on variable of premonsoon and $\mathrm{n}_{2}$ is the number of observations on variable of postmonsoon. If computed value is greater than critical value there is significant difference between means.

\subsection{RS and GIS Methodology}

The following RS and GIS methodologies were adopted for carrying out the research work.

\subsubsection{Supervised Classification of Study Area}

Supervised classification of the Burdwan town was performed with the help of Resourcesat-1 satellite image and Geomatica V.10.2 software. Map collected from Burdwan municipality was considered as base map (Figure 1). Base map was georeferenced at latitude/longitude projection system with a datum level of India-Nepal (D076) with an output pixel spacing of 0d00'00.1900". For georeferencing ground control points (GCPs) were collected from study area by using Germin 12 GPS receiver. Burdwan municipality area was clipped from the satellite imagery and image to image georeferencing was done by using already georeferenced base map. Then supervised classification was run by using maximum likelihood classifier with null class. Thereafter both landuse/landcover and base maps were reprojected to Universal Transverse Marcater Projection (UTM) system. Twenty five (25) air sampling locations were then downloaded to the classified image from GPS through Mapsource software. Locational details along with different air quality parameters and their concentrations were at- 
tached to this 25 spatial data as an attribute data.

\subsubsection{Digital Elevation Model (DEM)}

DEM is generated on the basis of sampling points, stored as a point layer along with attributes such as RSPM, $\mathrm{SO}_{2}$ and $\mathrm{NO}_{2}$ etc. DEM is generated by using VEDIMINT algorithm in the Geomatica V.10.1 software. The output DEM is represented as a zonation map of the said parameters (Figures 5, 6 and 7). The algorithm consists of three major steps plus an optional step for processing 2D features. In the first step, input vector points (RSPM, $\mathrm{SO}_{2}$ and $\mathrm{NO}_{2}$ concentration with respect to different locations) are reprojected to the raster coordinates and burned into the raster buffer, with the elevations generated due to different concentration of the said parameters interpolated linearly between vector nodes. 2D layers are ignored in this stage. If multiple elevation values are scanned into a single pixel, the maximum value is assigned the pixel, and the pixel is marked as a cliff. In the second step, the elevation at each DEM pixel is interpolated from the source elevation data. The interpolation process is based on an algorithm called Distance Transform. Interpolation is made between the source elevations and elevations at equal-distance points from source locations. If $2 \mathrm{D}$ vector layers are present, they are scan converted into a flag buffer during the optional step. The 2D features are also initialized to prepare for use in the smoothing stage. In step 3, a finite difference method is used to iteratively smooth the DEM grid. The algorithm uses over relaxation technique to accelerate the convergence. During the iterations, the source elevation values are never changed, while the interpolated values are updated based on the neighborhood values.

\subsubsection{Inverse Distance Interpolation (IDINT)}

Inverse distance interpolation is used to read the gray level values for an arbitrary number of pixel locations in order to generate a raster image based upon interpolation between the specified gray levels. This method of interpolation combines the idea of Thiessen polygon with the gradual change of trend surface. It considers weighted moving average. Weights are computed from a linear function of distance between sets of points and the points to be predicted. In this method the size of the starting radius is specified, which defines the starting search area for interpolation points around grid point.

\section{Results and Discussion}

Results of premonsoon and postmonsoon ambient air quality status of different monitoring sites of study area encompassing industrial, residential and sensitive areas are represented in Tables $\mathbf{6 , 7}$ and $\mathbf{8}$ respectively whereas the average seasonal values of RSPM, $\mathrm{SO}_{2}$ and $\mathrm{NO}_{2}$ are represented in Table 9.

\subsection{RSPM Scenario}

During premonsoon all the industrial sites had high level of RSPM than the standard prescribed by NAAQS. This might be due to resuspension of road dust, soil dust, and vehicular traffic and nearby industrial emission [8]. But during postmonsoon RSPM level in these sites lied well below the prescribed limit. This implied that the monsoon in these sites had a major role in washing out of RSPM [20].

In residential sites RSPM level exceeded its standard in every monitoring site except R7, R13, and R15 where the level of RSPM lied very near to the standard. But in postmonsoon opposite phenomenon was observed. Only $12 \%$ of residential sites i.e. $\mathrm{R} 11, \mathrm{R} 12$, and $\mathrm{R} 15$ have higher level of RSPM than the permissible standard. In general it is found that most of the postmonsoon RSPM concentration was significantly less than the premonsoon concentration except site R15. This phenomenon might be corroborated to monsoonal wash out of the particles [8]. The site R15 was situated just beside National Highway. So, at that particular time of monitoring high density of traffic, road dust etc might cause it to be more negating the effect of rain which was supported by similar observation of a research work [32].

Regarding sensitive sites except site S5 and S6 most of the RSPM value lied above the limit of NAAQS standard in premonsoon while in postmonsoon the level exceeds

Table 6. Premonsoon and postmonsoon ambient air quality status in various industrial locations of Burdwan municipality (Except AQI, all values are expressed in $\mu \mathrm{g} / \mathrm{m}^{3}$ ).

\begin{tabular}{|c|c|c|c|c|c|c|c|c|c|c|}
\hline \multirow[t]{2}{*}{ Sites } & \multicolumn{2}{|c|}{ RSPM } & \multicolumn{2}{|c|}{$\mathrm{SO}_{2}$} & \multicolumn{2}{|c|}{$\mathrm{NO}_{2}$} & \multicolumn{2}{|c|}{ AQI } & \multicolumn{2}{|c|}{ Status } \\
\hline & Pre & Post & Pre & Post & Pre & Post & Pre & Post & Pre & Post \\
\hline I1 & 173.9 & 74 & 1.59 & 20.34 & 26.62 & 125.78 & 15.05 & 44.33 & Clean & Fairly clean \\
\hline I2 & 326.2 & 53.7 & 26.69 & 23.11 & 66.06 & 60.29 & 64.33 & 32.59 & $\begin{array}{l}\text { Moderately } \\
\text { polluted }\end{array}$ & Fairly clean \\
\hline $\mathrm{I} 3$ & 154.6 & 55.2 & 8.6 & 0.38 & 20.19 & 98.6 & 23.16 & 9.80 & Clean & Very clean \\
\hline I4 & 231.1 & 60.41 & 19.46 & 7.51 & 56.09 & 23.91 & 48.88 & 17.12 & Fairly clean & Clean \\
\hline
\end{tabular}


Table 7. Premonsoon and postmonsoon ambient air quality status in various residential locations of Burdwan municipality (Except AQI, all values are expressed in $\mu \mathrm{g} / \mathrm{m}^{3}$ ).

\begin{tabular}{|c|c|c|c|c|c|c|c|c|c|c|}
\hline \multirow[t]{2}{*}{ Sites } & \multicolumn{2}{|c|}{ RSPM } & \multicolumn{2}{|c|}{$\mathrm{SO}_{2}$} & \multicolumn{2}{|c|}{$\mathrm{NO}_{2}$} & \multicolumn{2}{|c|}{ AQI } & \multicolumn{2}{|c|}{ Status } \\
\hline & Pre & Post & Pre & Post & Pre & Post & Pre & Post & Pre & Post \\
\hline $\mathrm{R} 1$ & 203.30 & 22.80 & 4.37 & 7.06 & 238.19 & 44.05 & 69.15 & 22.29 & $\begin{array}{c}\text { Moderately } \\
\text { polluted }\end{array}$ & Clean \\
\hline $\mathrm{R} 2$ & 174.70 & 15.46 & 0.88 & 1.47 & 161.79 & 90.73 & 33.87 & 14.76 & Fairly clean & Clean \\
\hline R3 & 230.00 & 34.26 & 2.13 & BDL & 109.74 & 230.51 & 43.79 & 16.60 & Fairly clean & Clean \\
\hline $\mathrm{R} 4$ & 303.30 & 38.92 & 0.34 & 10.60 & 29.19 & 163.69 & 16.75 & 47.25 & Clean & Fairly clean \\
\hline R5 & 267.30 & 71.80 & 2.21 & 6.95 & 63.15 & 191.21 & 38.77 & 71.37 & Fairly clean & $\begin{array}{c}\text { Moderately } \\
\text { Polluted }\end{array}$ \\
\hline R6 & 285.80 & 16.30 & 3.18 & 12.53 & 87.16 & 168.70 & 49.83 & 37.76 & Fairly clean & Fairly clean \\
\hline R7 & 99.40 & 40.97 & 0.6 & 9.11 & 36.77 & 129.66 & 15.04 & 42.29 & Clean & Fairly clean \\
\hline $\mathrm{R} 8$ & 135.17 & 32.63 & 0.34 & 3.94 & 88.36 & 193.90 & 18.51 & 33.90 & Clean & Fairly clean \\
\hline R9 & 119.16 & 10.00 & 3.17 & 20.34 & 63.04 & 207.12 & 33.38 & 40.38 & Fairly clean & Fairly clean \\
\hline $\mathrm{R} 10$ & 137.77 & 69.62 & 4.37 & 16.95 & 220.87 & 426.28 & 59.22 & 92.29 & $\begin{array}{l}\text { Moderately } \\
\text { polluted }\end{array}$ & Polluted \\
\hline R 11 & 323.10 & 112.80 & 6.93 & 5.45 & 140.43 & 79.05 & 78.90 & 42.35 & Polluted & Fairly clean \\
\hline $\mathrm{R} 12$ & 264.40 & 102.46 & 3.22 & 5.60 & 3.79 & 166.70 & 17.15 & 53.07 & Clean & $\begin{array}{l}\text { Moderately } \\
\text { polluted }\end{array}$ \\
\hline R13 & 69.61 & 47.16 & 2.69 & 1.32 & 16.10 & 30.34 & 16.76 & 14.34 & Clean & Clean \\
\hline R14 & 168.90 & 7.11 & 9.75 & 4.55 & 54.71 & 45.97 & 52.02 & 16.62 & $\begin{array}{l}\text { Moderately } \\
\text { polluted }\end{array}$ & Clean \\
\hline R15 & 96.54 & 141.00 & 2.72 & 6.00 & 158.82 & 97.99 & 40.24 & 50.60 & Fairly clean & $\begin{array}{c}\text { Moderately } \\
\text { polluted }\end{array}$ \\
\hline
\end{tabular}

Table 8. Premonsoon and postmonsoon ambient air quality status in various sensitive locations of Burdwan municipality (Except AQI, all values are expressed in $\mu \mathrm{g} / \mathrm{m}^{3}$ ).

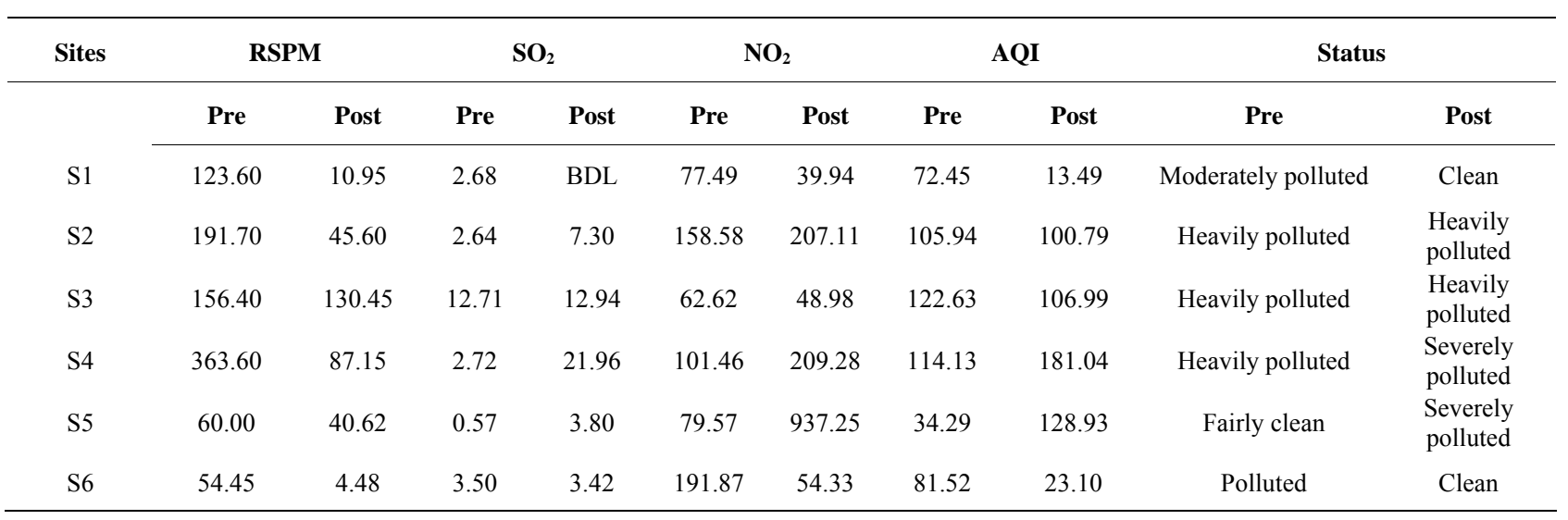

only at site S3 and S4. This might be due to their locational disadvantages as because both these two places were located in the region where majority rice mills factories of the town are situated. So, in spite of monsoonal wash out of dust particle they reflected a high level of RSPM than the standard. Maximum RSPM level during premonsoon was found in S4 site, which was not only beside rice mills but also beside a main road. So, such a high level of RSPM might be attributed to resuspension of road dust, soil dust and vehicular traffic and nearby industrial emission.

Digital elevation model (DEM) with respect spatiotemporal distribution of RSPM in the study area were presented in Figures 4(a) and (b). 
Table 9. Statistical summary of ambient air quality status of Burdwan municipality during pre and postmonsoon season.

\begin{tabular}{ccccccc}
\hline Statistics & \multicolumn{2}{c}{$\mathbf{R S P M}\left(\mu \mathrm{g} / \mathbf{m}^{3}\right)$} & \multicolumn{2}{c}{$\mathbf{S O}_{2}\left(\mu \mathbf{g} / \mathbf{m}^{3}\right)$} & \multicolumn{2}{c}{$\mathbf{N O}_{2}\left(\mu \mathbf{g} / \mathbf{m}^{3}\right)$} \\
\hline & Premonsoon & Postmonsoon & Premonsoon & Postmonsoon & Premonsoon & Postmonsoon \\
\cline { 2 - 6 } Average & 188.56 & 53.03 & 5.12 & 8.51 & 92.51 & 162.85 \\
Maximum & 363.6 & 141 & 26.69 & 23.11 & 238.19 & 937.25 \\
Minimum & 54.45 & 4.48 & 0.34 & BDL* & 3.79 & 23.91 \\
Standard deviation & 88.63 & 38.27 & 6.27 & 7.11 & 64.78 & 184.80 \\
\hline
\end{tabular}

*BDL indicated below detection limits

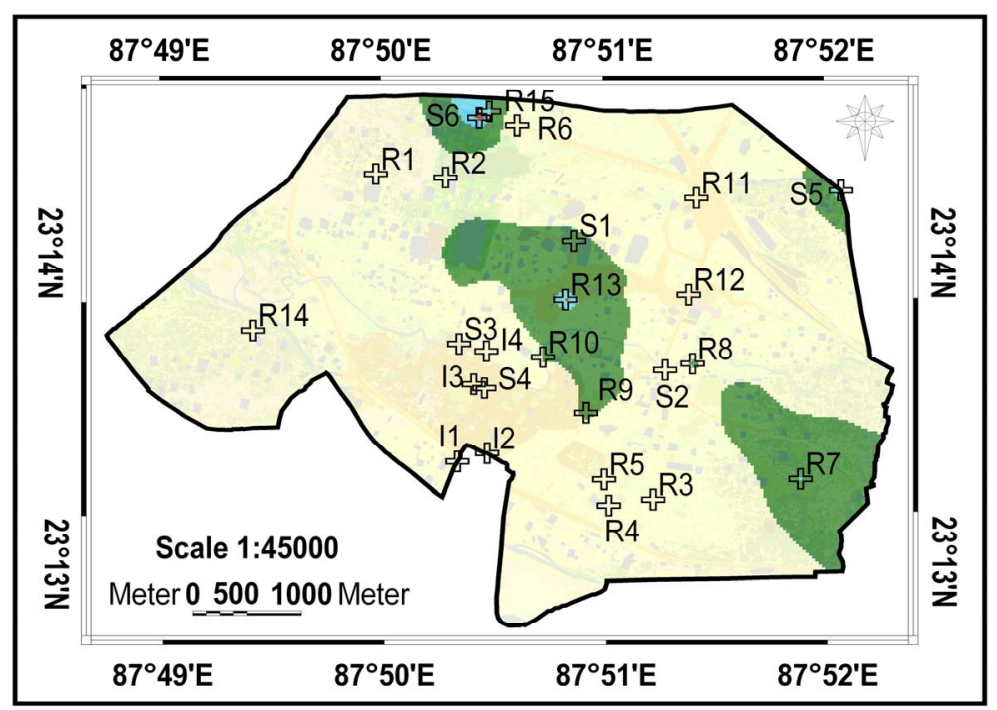

(a)
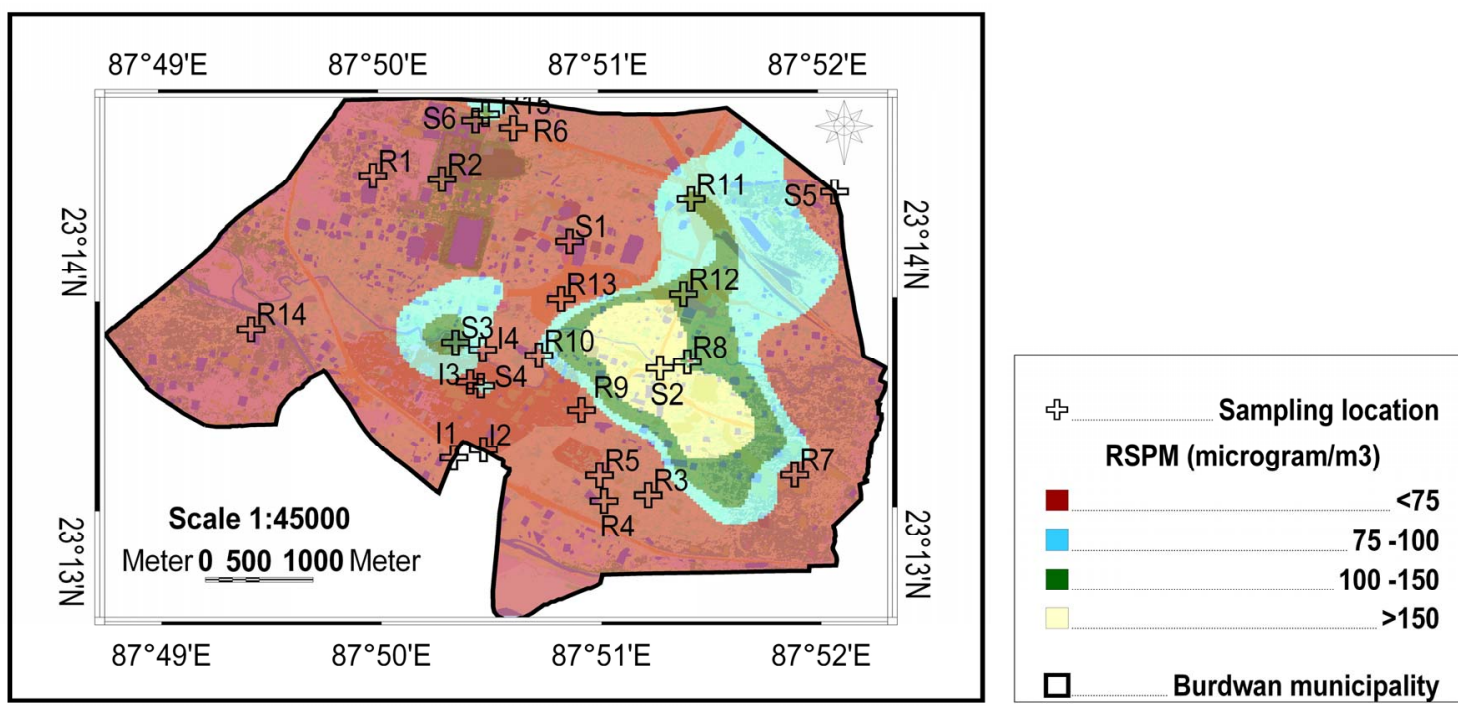

(b)

Figure 4. Digital Elevation Model (DEM) on spatio-temporal distribution of RSPM over the study area in (a) Premonsoon (b) Postmonsoon. 


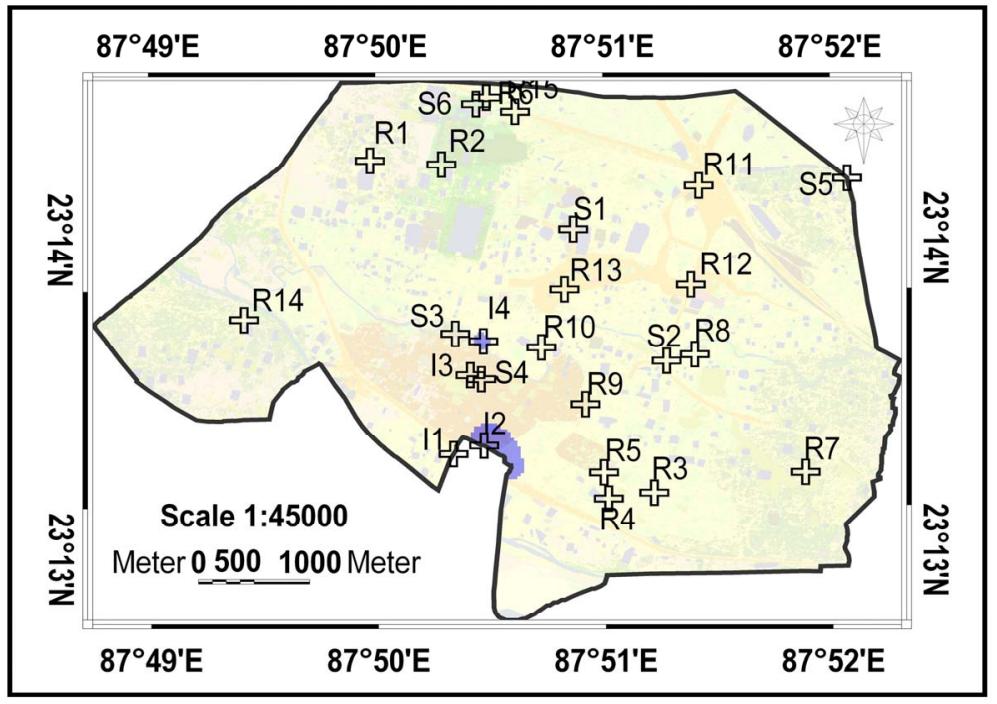

(a)
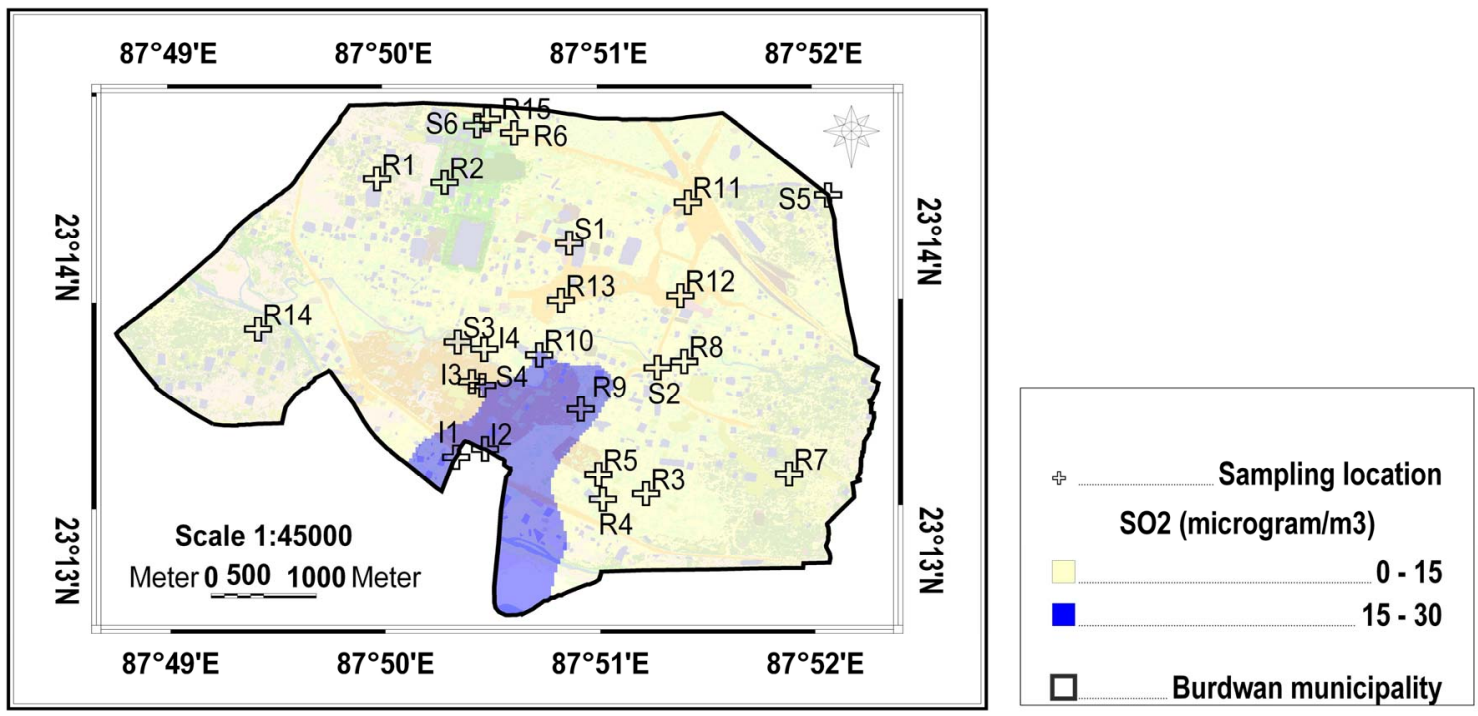

(b)

Figure 5. Digital Elevation Model (DEM) on spatio-temporal distribution of $\mathrm{SO}_{2}$ over the study area in (a) Premonsoon (b) Postmonsoon.

\section{2. $\mathrm{SO}_{2}$ Scenario}

The concentration of $\mathrm{SO}_{2}$ was comparatively lower in both the seasons than the prescribed standard of NAAQS in all the monitoring sites. Similar kind of $\mathrm{SO}_{2}$ status was also highlighted by other research workers such as Reddy and Ruj 2003 [21] and Gupta et al. 2008 [8]. Among industrial, residential and sensitive sites maximum $\mathrm{SO}_{2}$ level was observed in industrial sites i.e. $26.69 \mu \mathrm{g} / \mathrm{m}^{3}$ during premonsoon and $23.11 \mu \mathrm{g} / \mathrm{m}^{3}$ during postmonsoon. This might possibly be due to emission from industrial boiler, heating and cooking sources. Within in- dustrial sites except I1, rest of the three sites had low $\mathrm{SO}_{2}$ level during postmonsoon. While in case of residential sites most of the sites has higher level of $\mathrm{SO}_{2}$ concentration during postmonsoon except R3, R11, R13, R14 sites. Burning of coal by local people might influence it. Similar trend also followed by most of the sensitive sites except $\mathrm{S} 1$ and $\mathrm{S} 6$.

Spatio-temporal distribution of $\mathrm{SO}_{2}$ concentration are represented in Figures 5(a) and (b).

\section{3. $\mathrm{NO}_{2}$ Scenario}

Through out the study area $\mathrm{NO}_{2}$ level was very high. Ma- 


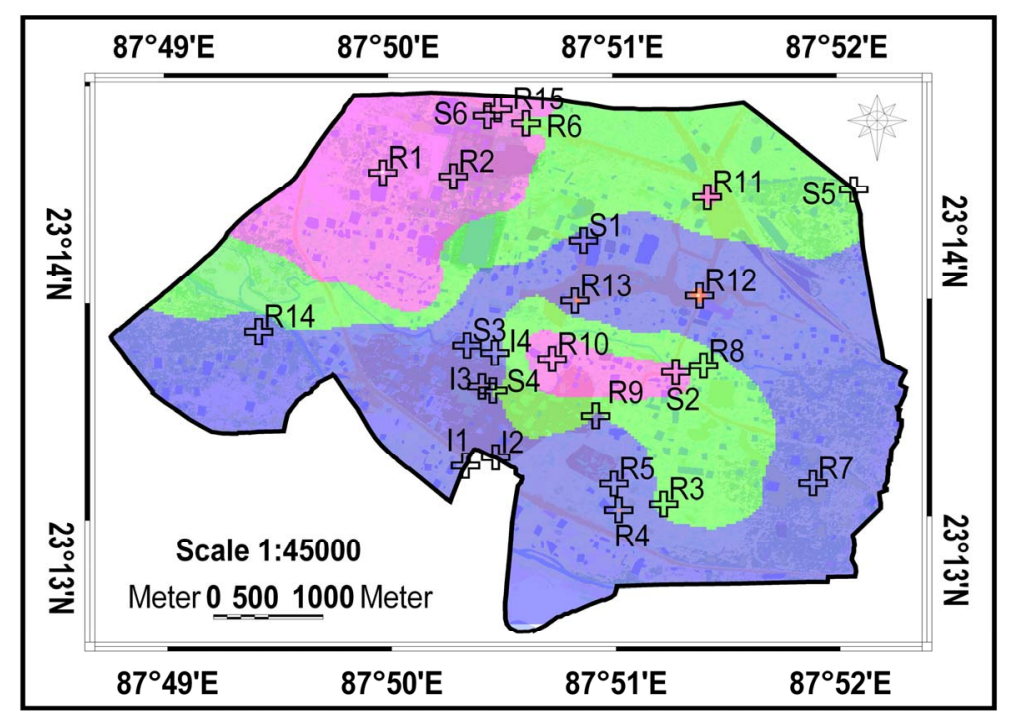

(a)
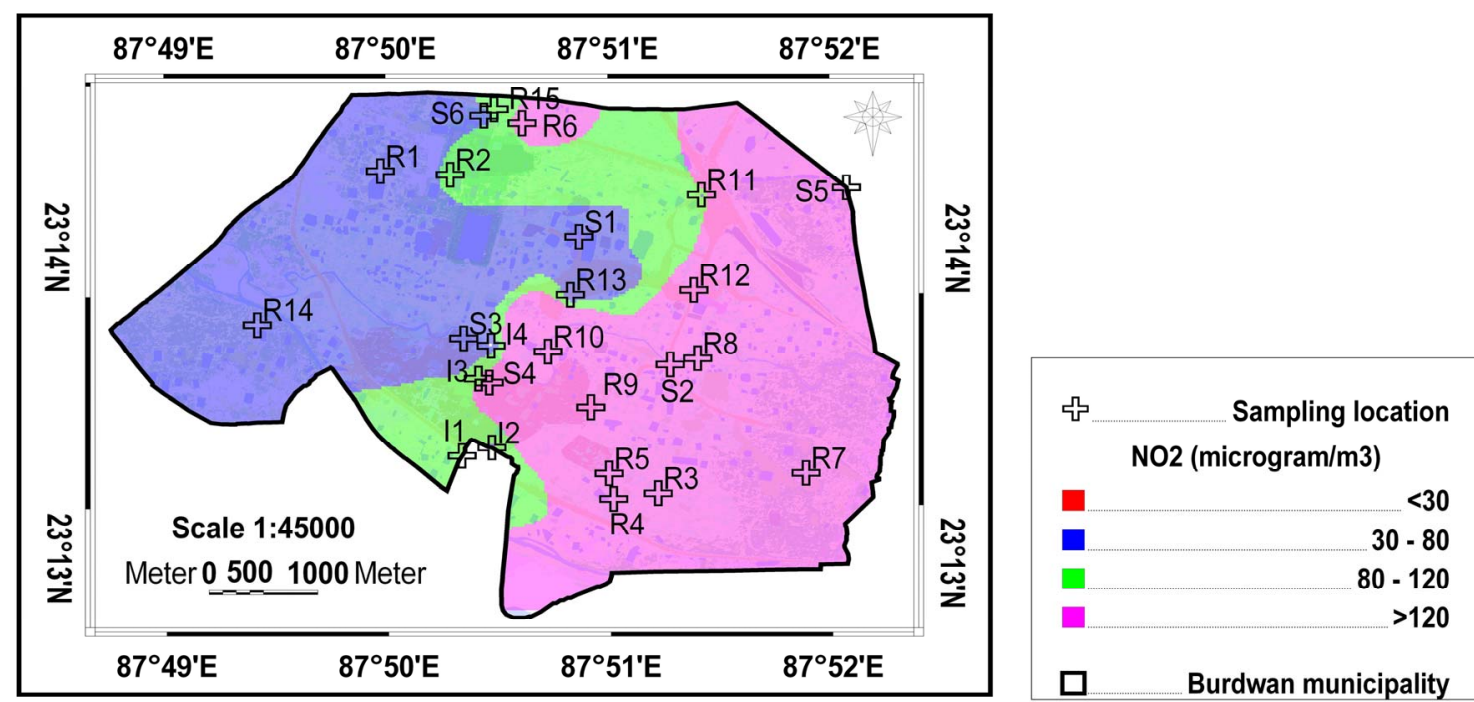

(b)

Figure 6. Digital Elevation Model (DEM) on spatio-temporal distribution of $\mathrm{NO}_{2}$ over the study area in (a) Premonsoon (b) Postmonsoon.

ximum concentration was observed in S5 site in the tune of $937 \mu \mathrm{g} / \mathrm{m}^{3}$. This elevated level might be attributed to the high traffic density of the town. This was also supported by a published work of [33]. Among industrial sites, $\mathrm{I} 2$ and $\mathrm{I} 4$ show the low level of $\mathrm{NO}_{2}$ concentration in postmonsoon while in the same season high concentration was observed in site I1, I13. To explain the later it could be said $\mathrm{NO}_{2}$ was not only dependent on rainfall but also dependent on vehicle density and the distance of the monitoring site from road [18]. Among all industrial sites only site $\mathrm{I} 1$ had the higher-level of $\mathrm{NO}_{2}$ than the standard in postmonsoon season. Regarding residential sites, R1,
R2, R3, R6, R8, R10, R11, R15 had higher level of $\mathrm{NO}_{2}$ concentration in premonsoon season while in postmonsoon except R1, R11, R13, R14 all have shown higher level of $\mathrm{NO}_{2}$ than the prescribed standard. In the sensitive sites both the pre and postmonsoon value of $\mathrm{NO}_{2}$ were exceeded its standard.

Digital elevation model with respect to spatio-temporal distribution of $\mathrm{NO}_{2}$ were represented in Figures 6(a) and (b).

\subsection{Overall Scenario of RSPM, $\mathrm{NO}_{2}$ and $\mathrm{SO}_{2}$}

Average concentration level of all the pollutants in both 


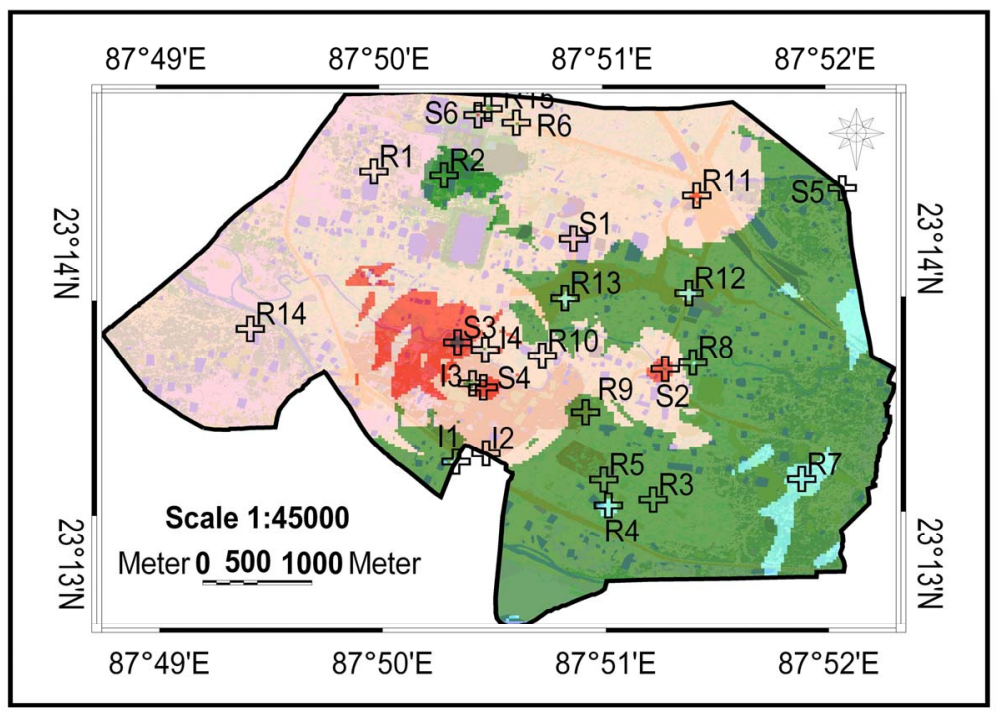

(a)
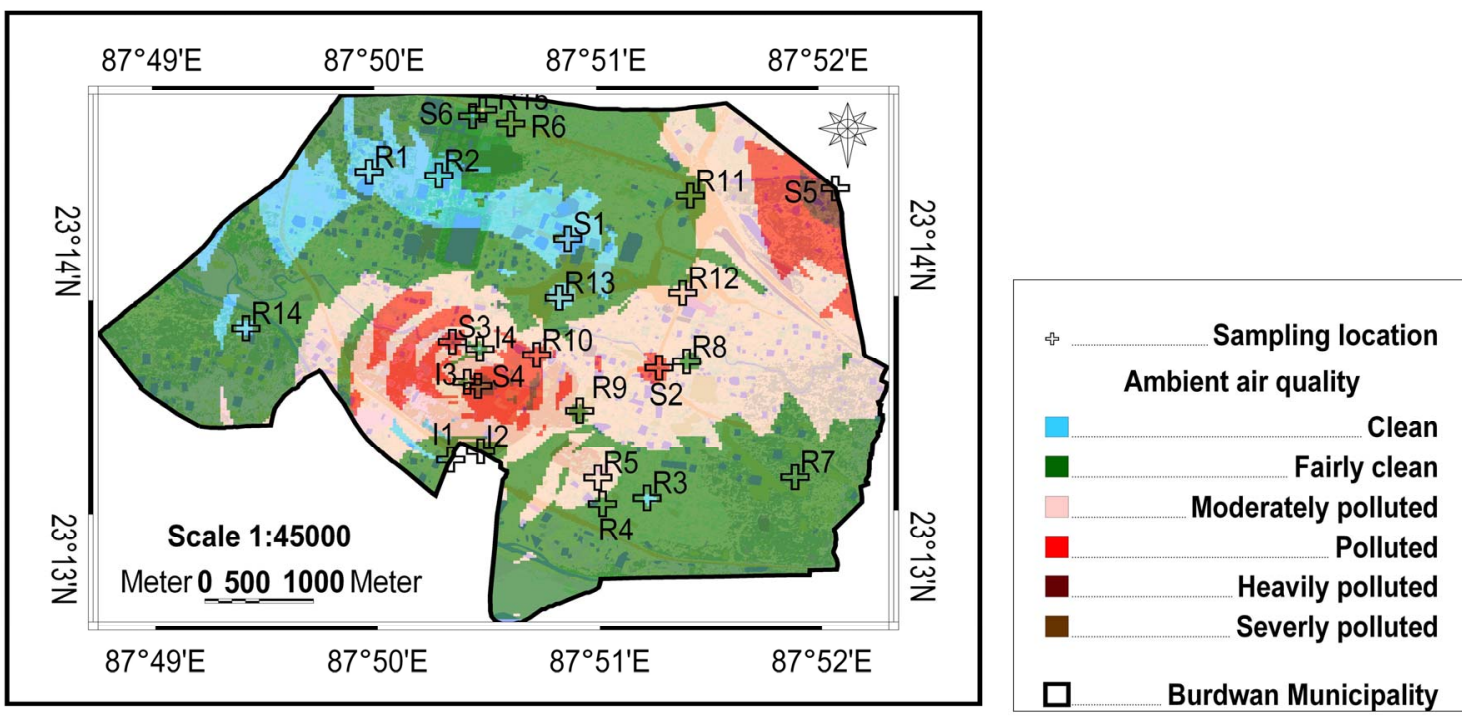

(b)

Figure 7. Continuous surfaces from point data (AQI) by using Inverse Distance Interpolation (IDINT) technique in (a) Premonsoon (b) Postmonsoon.

the season was represented in Table 9. In general RSPM level varied from 363 to $54 \mu \mathrm{g} / \mathrm{m}^{3}$ with a mean of 188 $\mu \mathrm{g} / \mathrm{m}^{3}$ in premonsoon and from 141 to $4.48 \mu \mathrm{g} / \mathrm{m}^{3}$ with a mean of $53.03 \mu \mathrm{g} / \mathrm{m}^{3}$ during postmonsoon season. $\mathrm{NO}_{2}$ level varied from 3 to $238 \mu \mathrm{g} / \mathrm{m}^{3}$ with a mean of 92 $\mu \mathrm{g} / \mathrm{m}^{3}$ and 23 to $937 \mu \mathrm{g} / \mathrm{m}^{3}$ with a mean of $162 \mu \mathrm{g} / \mathrm{m}^{3}$ respectively during premonsoon and postmonsoon season. Whereas $\mathrm{SO}_{2}$ level varied from 0.34 to $26 \mu \mathrm{g} / \mathrm{m}^{3}$ with a mean of $5 \mu \mathrm{g} / \mathrm{m}^{3}$ and BDL to $23 \mu \mathrm{g} / \mathrm{m}^{3}$ with a mean of 8 $\mu \mathrm{g} / \mathrm{m}^{3}$ respectively during premonsoon and postmonsoon season. Finally, to compare the pre and the postmonsoonal value of $\mathrm{SO}_{2}$ and $\mathrm{NO}_{2}$ in this town it was found that in most places the level of $\mathrm{SO}_{2}$ as well as $\mathrm{NO}_{2}$ was increased in postmonsoon season in spite of lowering down by rain. This might be explained by over crowded condition in the town of Burdwan, which was also the center of commercial activities in the district. The building structures were constructed literally wall to wall with very narrow streets separating one block from the other. Even the vehicular traffic was at most times bumper to bumper and sometimes at a stand still every time it rained. Hence, the increased amount of exhaust gases in the air negated the effect of the monsoon rains [32].

Statistical significance (student $t$-test) of seasonal vari- 
ation of air quality parameters were carried out for the combined data of pre- and postmonsoon. Result of t-test for the combined data was given in Table 10. The Table value (critical value) at 48 degree of freedom was 1.68 for left-sided alternative hypothesis. Since the computed values of $t$ were greater than the critical value of 1.68 for all the parameters the difference of means between pre and postmonsoon was significant at 5\% level. Hence, the results clearly indicated that there was significant monsoonal effect on mean values of RSPM, $\mathrm{SO}_{2}$ and $\mathrm{NO}_{2}$

\section{Influence of Meteorological Parameters}

In the study area premonsoon temperature ranged from 16 to $35^{\circ} \mathrm{C}$ while in postmonsoon it varied from 16 to $33^{\circ} \mathrm{C}$. Humidity ranged from 42 to $75 \%$ and 53 to $85 \%$ during premonsoon and postmonsoon season respectively (Table 4). Regarding rainfall study area received an average rainfall of $78 \mathrm{~mm}$ in premonsoon where as in postmonsoon it receives $324 \mathrm{~mm}$. Windrose which was graphical representation of wind data giving the $\%$ frequencies of wind speed, wind direction for a given location was represented in Figures $\mathbf{3}$ and $\mathbf{4}$ for premonsoon and postmonsoon season respectively. From windrose diagrams it was found that the percentage of calm condition is higher $(11 \%)$ in postmonsoon than premonsoon season $(3 \%)$. As a result, higher concentration of gaseous pollutants was observed in postmonsoon than the premonsoon in the study area of this town. The wind speed ranged between 0 to $18 \mathrm{~km} / \mathrm{hr}$. Wind blew almost from all direction. But during premonsoon the predominant direction was from North-East, South-East and SouthWest direction while in postmonsoon season it was mainly from South-East, South-Southwest and North direction also. The major significant changes in the spatial and temporal variation of the ambient air quality of the town were due to variation of rainfall in the two seasons which was also supported by the Table $\mathbf{1 0}$.

\section{Season-Wise Classified Image on the Basis of Air Quality Index (AQI)}

Air Quality Index of all the three categories of monitoring sites was represented in Tables 6, 7 and 8. From AQI status of the all monitoring sites in both pre- and postmonsoon season it was found that $40 \%$ of the total monitoring sites (I4, I2, I3, R1, R2, R3, R11, R14, S6, S1) became less polluted in postmonsoon. Whereas $40 \%$ of the total monitoring sites (I1, S4, S5, R4, R5, R7, R8, $\mathrm{R} 10, \mathrm{R} 12, \mathrm{R} 15)$ became more polluted in postmonsoon season and $20 \%$ of the total monitoring sites (R6, R9, $\mathrm{R} 13, \mathrm{~S} 2, \mathrm{~S} 3)$ remained same in status i.e. they are indifferent of rainy season and by using IDINT technique, season wise continuous surfaces of AQI have been gen-
Table 10. Student t-test of mean difference between air quality parameters.

\begin{tabular}{cccc}
\hline Parameter & $\begin{array}{c}\text { Calculated } \\
\text { t value }\end{array}$ & $\begin{array}{c}\text { Tabulated value of } \mathbf{t} \\
\text { at } \mathbf{0 . 0 5} \text { level }\end{array}$ & $\begin{array}{c}\text { Significant/ } \\
\text { Insignificant }\end{array}$ \\
\hline $\mathrm{RSPM}$ & 6.88 & 1.677 & Significant \\
$\mathrm{SO}_{2}$ & -1.7519 & 1.677 & Significant \\
$\mathrm{NO}_{2}$ & -1.7597 & 1.677 & Significant \\
\hline
\end{tabular}

Table 11. Season-wise percentage area of different AQI status.

\begin{tabular}{ccc}
\hline \multirow{2}{*}{ AQI status } & \multicolumn{2}{c}{ Seasonal areal coverage (\%) } \\
\cline { 2 - 3 } & Premonsoon & Postmonsoon \\
\hline Clean & 2.19 & 9.43 \\
Fairly clean & 41.09 & 52.02 \\
Moderately & 53.37 & 30.18 \\
polluted & 3.30 & 7.52 \\
Polluted & 0.05 & 0.82 \\
Heavily polluted & Nil & 0.03 \\
Severely polluted &
\end{tabular}

erated. The output surfaces generated by IDINT were unclassified grey scale images. Though output surfaces were smooth but it is difficult to compare these surfaces on the basis of seasonal trend. On the basis of AQI rating, and using classification technique, these seasonal images had been classified (Figures 7(a) and (b)). Premonsoon classified image revealed that the western part of the town mainly covered the moderately polluted area while the eastern part of the town covers the fairly polluted region. But after the offset of monsoon just opposite scenario was observed. The moderately polluted region was seemed to be shifted to eastern part while the fairly clean part was shifted to western part. This phenomenon was also influenced by meteorological phenomenon which might be supported by wind rose diagram. It was observed that in premonsoon season wind mainly blew from North-East, South-East and South-West direction. It looked that the pollutants were seemed to be dispersed more in these direction from the polluted region. In postmonsoon just opposite picture was found. The predominant wind direction was South, South-West and North direction. So, the just opposite dispersion of pollutants had been occurred from the heavily polluted region. According to IDINT surface classification on the basis of AQI clean and fairly clean area had increased upto $7 \%$ and $2 \%$ respectively in comparison to premonsoon, whereas moderately polluted classified area decreased to 23\% (Table 11). 


\section{Acknowledgements}

The authors gratefully acknowledge Dr A. R. Ghosh, Reader, Department of Environmental Science, Burdwan University for his critical evaluation and suggestion, and suggestions, which greatly helped to improve the manuscript.

\section{REFERENCES}

[1] D. W. Dockery, C. A. Pope, X. Xu, J. D. Splender, J. H. Ware, M. E. Fay, B. G. Ferris and F. E. Speizer, "An Association between Air Pollution and Mortality in Six US cities, New England," Journal of Medicine, Vol. 329, No. 24, 1993, pp. 1753-1759.

[2] P. J. Koken, W. T. Piver, F. Ye, A. Elixhauser, L. M. Olsen and C. J. Portier, "Temperature, Air Pollution and Hospitalization for Cardiovascular Diseases among Elderly People in Denver," Environmental Health Perspectives, Vol. 111, No. 10, 2003, pp. 1312-1317.

[3] United Nations Environment Programme, "Global Environment Outlook," Earthscan, London, 1999.

[4] A. K. Azad and T. Kitada, "Characteristics of the Air Pollution in the City of Dhaka, Bangladesh in Winter," Atmospheric Environment, Vol. 32, No. 11, 1998, pp. 1991-2005.

[5] A. Salam, H. Bauer, K. Kassin, S. M. Ullah and H. Puxbaum, "Aerosol Chemical Characteristics of a Mega-City in southeast Asia (Dhaka, Bangladesh)," Atmospheric Environment, Vol. 37, No. 18, 2003, pp. 2517-2528.

[6] B. A. Begum, E. Kim, S. K. Biswas and P. K. Hoopke, "Investigation of Sources of Atmospheric Aerosol at Urban and Semi Urban Areas in Bangladesh," Atmospheric Environment, Vol. 38, No. 19, 2004, pp. 3025-3038.

[7] H. Cahier, A. F. ulagnier, R. Sarda, F. Gautier, P. Masclet, J. L. Besombes, et al., "Aerosol Studies during the ESCOMPTE Experiment: An Overview," Atmospheric Research, Vol. 74, No. 1-4, 2005, pp. 547-563.

[8] A. K. Gupta, K. Karar, S. Ayoob and K. John, "SpatioTemporal Characteristics of Gaseous and Particulate Pollutants in an Urban Region of Kolkata, India," Atmospheric Research, Vol. 87, No. 2, 2008, pp. 103-115.

[9] M. K. Ghose, R. Paul and S. K. Banerjee, "Assessment of the Impacts of Vehicular Emissions on Urban Air Quality and its Management in Indian Context: The Case of Kolkata (Calcutta)," Environmental Science and Policy, Vol. 7, No. 4, 2004, pp. 345-351.

[10] D. Mage, G. Ozolins, P. Peterson, A. Webster, R. Orthofer, V. Vandeweerd and M. Gwynne, "Urban Air Pollution in Mega Cities of the World," Atmospheric Environment, Vol. 30, No. 5, 1996, pp. 681-686.

[11] A. Salam, T. Hossain and M. N. A. Siddique, "Characteristics of Atmospheric Trace Gases, Particulate Matter, and Heavy Metal Pollution in Dhaka, Bangladesh," Air Quality Atmosphere and Health, Vol. 1, No. 2, 2008, pp. 101-109.

[12] M. Ali and M. Athar, "Air Pollution Due to Traffic, Air
Quality Monitoring along Three Sections of National Highway N-5, Pakistan," Environmental Monitoring and Assessment, Vol. 136, No. 1-3, 2008, pp. 219-226.

[13] P. Goyal and Sidhartha, "Present Scenario of Air Quality in Delhi: A Case Study of CNG Implementation," Atmospheric Environment, Vol. 37, No. 38, 2003, pp. 54235431.

[14] P. D. Sharma, "Ecology and Environmrnt," 10th Edition, Rastogi Publishres, Meerut-New Delhi, 2007, p. 395.

[15] A. Verma, S. N. Singh and M. K. Shukla, "Air Quality of the Trans-Gomati Area of Lucknow City, India," Bulletin of Environmental Contamination and Toxicology, Vol. 70, No. 1, 2003, pp. 166-173.

[16] C. P. Kaushik, K. Ravindra, K. Yadav, S. Mehta and A. K. Haritash, "Assessment of Ambient Air Quality in Urban Centers of Haryana (India) in Relation to Different Anthropogenic Activities and Health Risks," Environmental Monitoring and Assessment, Vol. 122, No. 1-3, 2006, pp. 27-40.

[17] M. Pulikesi, B. P. Skaralingam, D. Elango, V. N. Rayudu, V. Ramamurthi and S. Sivanesan, "Air Quality Monitoring in Chennai, India, in the Summer of 2005," Journal of Hazardous Materials, Vol. 136, No. 3, 2006, pp. 589596.

[18] S. Lal and R. S. Patil, "Monitoring of Atmospheric Behaviour of NOX from Vehicular Traffic," Environmental Monitoring and Assessment, Vol. 68, No. 1, 2001, pp. 37-50.

[19] M. K. Jain and N. C. Saxena, "Air Quality Assessment along Dhanbad-Jharia Road," Environmental Monitoring and Assessment, Vol. 79, No. 3, 2002, pp. 239-250.

[20] G. S. Reddy and B. Ruj, “Ambient Air Quality Status in Raniganj-Asansol Area, India," Environmental Monitoring and Assessment, Vol. 89, No. 2, 2003, pp. 153-163.

[21] S. J. Song, "A GIS Based Approach to Spatio-Temporal Analysis of Urban Air Quality in Chengdu Plain," The International Achieves of the Photogrammetry, Remote Sensing and Spatial Information Sciences, Vol. 37. Part B7, Beijing, 2008.

[22] C. H. Yeang, Jr., F. Joseph and A. Ismail, "Distributed GIS for Monitoring and Modeling Urban Air Quality," Proceedings of the 6th International Conference in Urban Planning and Urban Management, Venice, September 1999; subsequently, in Italian, in the journal Urbanistica, October 2000, p. 114.

[23] G. C. Mulaku and L. W. Kariuki, "Mapping and Analysis of Air Pollution in Nairobi, Kenya," International Conference on Spatial Information for Sustainable Development, Nairobi, Kenya, 2-5 October 2001.

[24] U. Patil, "GIS Based Air Pollution Surface Modeling," GIS@Development, August 2003.

[25] L. Matejicek, "Spatial Modeling of Air Pollution in Urban Areas with GIS: A Case Study on Integrated Database Development," Advances in Geosciences, Vol. 4, 2005, pp. 63-68.

[26] P. B. L. Murty, "Environmental Meteorology," I.K. In- 
ternational Pvt. Ltd, New Delhi, 2004, p. 152.

[27] P. D. West and G. C. Gaeke, "Fixation of Sulphur Dioxide as Sulfitomercurate (II) and Subsequent Colorimetric Estimation," Analytical Chemistry, Vol. 28, 1956, pp. 1816-1819.

[28] M. B. Jacobs and S. Hochcheiser, "Continuous Sampling and Ultra Microdetermination of Nitrogen Dioxide in Air," Analytical Chemistry, Vol. 30, No. 3, 1958, pp. 426428.

[29] T. N. Tiwari and M. Ali, "Air Quality Index for Calcutta and its Monthly Variation for Various Localities," Indian Journal of Environmental Protection, Vol. 7, No. 3, 1987, pp. 172-176.
[30] S. S. Mudri, "Categorisation of Ambient Air Quality Index," Indian Journal of Environmental Protection, Vol. 10, 1990, pp. 424-427.

[31] N. Gurumani, "An Introduction to Biostatistics," MJP Publishers, Chennai, 2005, p. 600005.

[32] I. Valeroso and C. A. Monteverde, "Diurnal Variations of Air Pollution over Metropolitan Manila," Atmosfera, Vol. 5, 1992, pp. 241-257.

[33] Q. Weng and S. Yang, "Urban Air Pollution Patterns, Land Use, and Thermal Landscape: An Examination of the Linkage Using GIS," Environmental Monitoring and Assessment, Vol. 117, No. 1-3, 2006, pp. 463-484. 